\title{
Proposed Revision of the Mining Law with Respect to Discovery*
}

Much has been written of late regarding the proposed revision of the United States Mining Statutes. There seems to be a strong current running in the direction of such revision and the probabilities are that Congress will, in the near future, be urged to radically amend the existing law, if not adopt an entirely new systein.

It is, therefore, of the utmost importance that such action should be taken only after mature deliberation. The proposed changes and the reasons underlying such changes, should be subjected to the most searching scrutiny, while the probable effect on the mining industry of the laws to be substituted for those now existing should receive the most careful and critical consideration. That the general excellence of the existing law has been a material factor in the wonderful development of our mineral resources must be generally conceded. The results have abundantly justified the sagacity of the framers of the act, and for this reason, if we have outgrown the system or if some of its provisions require amendment, it would seem that the burden is on the critics to establish beyond a reasonable doubt that what they offer as a substitute will accomplish the results claimed. Unless they can practically guarantee that what they offer will materially improve existing conditions, the move will be a dangerous one and may have a disastrous effect on mining in general. Most of the criticism aimed at the existing law is of a superficial character and throws but little light on actual conditions.

The object of this comment is to call specific attention to some of the important details which, so far as the writer is aware, have not been satisfactorily treated by the advocates of revision. The two most radical changes proposed are the abolition of

*AUTHOR'S NOTE.-A portion of the material used in this article has been prepared for and permission to publish given by the Carnegie Institution of Research, Washington, $D$. C. The author is also indebted to his wife, Rachel Vrooman Colby, for valuable aid in translation of foreign authorities on mining law. 
the extralateral right, and the doing away with the necessity of making a discovery. Those who advocate the first change are consistent in recommending the second. If the right to follow a vein down on its dip underneath adjoining ground is denied, and vertical side boundaries are to control, then obviously discovery on claims overlying the dip of the vein and situated several hundred feet from the apex would only be possible after great expenditure of time and labor. A shaft would have to be sunk from the surface of such outlying claims to intersect the vein in depth if the requirement of discovery on each separate claim be retained.

Is it wise that we should wipe out this existing discovery requirement? Let us examine the underlying reasons and anticipate if possible the consequences which must inevitably result from its abolition. Some un-informed critics of the present law have referred to its discovery requirements as being 'an impossibility of mining law originating in America.' No one at all conversant with the origin of the discovery requirement in the mining laws of the world could possibly stand sponsor for such a statement. As Judge Lindley, in his classic work on the 'Law of Mines,' has said:

Sec. 335. Discovery the Source of the Miner's Title. -Discovery in all ages and all countries has been regarded as conferring rights or claims to reward. Gamboa, who represented the general thought of his age on this subject, was of the opinion that the discoverer of mines was even more worthy of reward than the inventor of a useful art. Hence, in the mining laws of all civilized countries the great consideration for granting mines to individuals is discovery.

The right of a discoverer of a mine to have the preference in the concession is recognized in the mining law of nearly every country of continental Europe. In Germany in the Middle Ages, in the famous mining district of Joachimsthal, free prospectors' licenses (Frei Schurfen) were granted, but they gave rise to so much quarreling that they were finally abolished. Thereafter it was declared that:

"The mining regions shall be free to every miner, who shall have the right to prospect therein according to his opportunity, without the necessity of securing previous permission. Whoever, thro' the grace of God, first discovers a vein 
shall be termed 'the first discoverer' and he shall have the first discoverer's right, viz: a Fundgrube (discoverer's claim). . . . The Mining Director shall grant the location to no one else.

Locators of claims (Massen) adjoining the discoverer's claim had I4 days withm which to discover and expose a vein in such adjoining locations. ${ }^{1}$ These regulations are typical of those which governed in other mining regions of Germany and Austria.

In more modern times in Germany the discovery of a vein must be followed by its regular denunciation. The actual discoverer has, for one week after his discovery, the prior claim. As in our American law, the discovery point must lie within the claim as laid out. $^{2}$

The French ${ }^{3}$ and Belgian law of mimes, while not giving the discoverer an absolute preference to the concession of a mine, placed him in the list of preferred applicants. The Spanish and Mexican laws were still more liberal, for they secured to the discoverer an absolute right of property in the mine which he discovered and denounced, and no one could have any preference over him. Other persons who came after the first discoverer were entitled to take up claims "as they shall discover ore." They could not set up stakes unless they had first discovered ore. In

1 The foregoing information is found in "Speculum Juris Metallici," by Sebastian Span. It is one of the most comprehensive treatises on mining law of the early Germanic period and was published in 1698.

2 In this connection it is interesting to note the following criticism of the French mining law and the proposal that France adopt the very feature of discovery which it is suggested that we now discard: 'The principal objection that is taken to the French System of mining law seems to be that there is too much State control, especially in the matter of granting concessions, it being left to the pleasure of the State whether the mine should be granted or not and to whom it should be granted; whilst in other countries the discoverer (as in Germany) . . . . is entitled to a grant of the concession.

The report of a Commission of the Chamber of Deputies proposed the following alterations: The recognition of the right to the concession of the discoverer, who oroves the existence of a bed of mineral substance. This is practically an adoption of the German system of institution of ownership. They also remark that England and the United States are almost in complete possession of a law as wise in its simplicity as that which they indicate as the perfection of mining law; that everywhere the regalien right is being assailed; that everywhere the power of the State in such matters is being restrained; and that everywhere greater belief is being placed in private enterprise and in industrial liberty, and that it is a remarkable fact that the more this faith increases the more mineral wealth is developed.'

Walmesley, Guide to the Mining Laws of the World, pp. 50-52.

3 'Modern German Codes,' by Raymond, 'Mineral Resources,' 1869. 
Austria and Hungary, in upper Italy, Portugal, Sweden, Norway, certain cantons of Switzerland, and parts of Russia the "first finder" or he who first discovered a veim, layer, mass or bed of ore, had a right to receive the concession in preference to any third party. ${ }^{4}$ In England in the lead-mining districts of Derbyshire, where the right of free mining existed, the discoverer of a mine was entitled as a inatter of right to have his claim allotted him by the Barmaster, but this could not be done "till Ore be gotten in the same ground to free it withal."5 The discoverer of mines Royal in England was by the rules of the 'Societies of the Mines Royal,' etc., granted a lease of a certain area including such mine. ${ }^{\circ}$

It may seem strange that countries like Spain, France and Italy should have requirements in their mining codes so similar to those of Germany. Germany was the birthplace of free mining, and one would naturally expect the Roman and civil law to have had greater influence in moulding the mining institutions of these other countries bordering on the Mediterranean. This is not the fact, however. The German States had made such a success of mining, and developed the art to such a high degree, that all of the other European countries were compelled to look to it for enlightenment. In doing so they also assimilated some of the ideas of free mining which had there attained so vigorous a growth. Gamboa, in his famous 'Commentaries on the Mining Ordinances of Spain,' states that the King of Spain appointed a commission to examine the mining laws of the world with the idea of selecting those best suited to the development of the provinces in the New World, and that after exhaustive consideration, those of Germany, with their right of free mining, were found best adapted. ${ }^{7}$

Extensive research confirms the conclusions of the foregoing authorities. Discovery, as we are familiar with it sprang into

4 Walmesley, "Mining Laws of the World"; Hoover's translation of Agricola, pp. 81, 82, note; Halleck's 'De Fooz on the Iraw of Mines'; Delebecque, 'Legislation des Mines'; Blavier, 'Jurisprudence des Mines'; and Gamboa, "Ordenanzes de Minas," are authority for the foregoing statements.

5 'The Compleat Miner, Houghton, 1681; Bainbridge, 'Mines and Minerals' (5th. ed.), pp. 150-151.

6 Pettus, "Fodinae Regales" p. 76 (1670).

7 Gamboa, "Commentarios a las Ordenanzes de Mines" (1761), p. 6. As to the influence of German mining law on that of France, see 'Das Französische Bergrecht,' Achenbach, Pp. 28-29; and for the French and Austrian influences on the mining laws of the various States of Northern Italy, see Walmesley, 'Mining Laws of the World,' pp. $91-112$. 
existence contemporaneously with the assertion of the free miner's riglit. This was an early Germanic institution, similar in its origin to other examples of an exercise of free and independent personal privilege, as opposed to the restraint of despotic sovereignty, which have been handed down to us and become a part of our own institutions. The free miner's right involved the privilege of going out on land, usually wild and uncultivated, even though owned by some prince or royal owner, (this being the equivalent of our public domain), and discovering and locating a mining claim without the express permission of such owner. This right became so general and so well established, that the royal owners were finally forced to recognize it as a valid custom, and thereby yielded up one of their prerogatives of ownership. In short, the free miner decided for himself what land he would locate, and the ostensible owner of the land had very little or nothing to say about who should be allowed to work his mineral lands. A discovery was essential in order to identify the land claimed, stamp it with mineral character, and segregate it from the great bulk of surrounding land. This free miner's right was confined to mineral land, and the burden of establisling it to be mineral devolved on the free miner, and hence the necessity of discovery which furnished his proof. It was the simplest and most practical test. This same institution of free mining, somewhat modified by circumstances, can be traced into the lead districts of Derbyshire, England, and it was accompanied by the same requirement of discovery founded on the same necessities.

While it is impossible to state that the so-called American mining law which sprang up in the West following the discovery of gold, was directly patterned after the Germanic or Derbyshire prototypes, it is certam that our law in its genesis owes much to the spirit and reason underlying these other systems of mining law with their free miner's right. Here in the West, in the early days, the miners exercised the same free right to go out on the public domain to discover and locate mining claims. The sovereign power did not undertake to assert its prerogative, as it might have done, by designating those who should be permitted to work its mineral lands, but it gave full sway to the choice of the individual locators and passively allowed them to make their own rules and regnlations. This free miner's right, first embodied in the rules and customs of the mining districts, was later crystallized and codified into the federal statutes. For 
the same reasons which have existed ever since the free miner's right was first exercised, the principle of discovery was thus recognized and incorporated into the American mining law. It was necessary for the individual exercising this free right himself to stamp as mineral in character the land he sought to select, and the only feasible way in which he could do this was to make a discovery of mineral. This served a double purpose, for it furnished evidence of good faith on his part in claiming the land as mineral, and also segregated it from the public domain and prevented its acquisition by others who might seek to acquire it under the agricultural laws. As the law now stands, the miner is given the preference, and he can ordinarily defeat any agricultural claimant, even up to the time of entry for patent, by making a valid discovery of mineral on the land in controversy. By doing away with the necessity of discovery what will result? No longer is the mineral claimant afforded a convenient test as to the character of the land, which it is now within his power to make, but he must look elsewhere for the determination of the controversy. Who shall decide whether the land is mineral or agricultural in character, and how? Those who advocate the abolition of this test overlook the fact that an agricultural claimant may file on the same land. They must offer some substitute which will not only work as well as the test which they seek to supplant, but to justify the change they should offer a better test. It may be that they have such a test in mind, though it is impossible that they can have one which has withstood the wear and tear of centuries as has the one they would discard-one which was created by the miners themselves.

It has been suggested that the Government shall determine whether any particular tract of land is mineral or non-mineral. This means an intensive classification of the millions of acres comprising the 'public domain.' While this land is being classified, what is to be the status of mineral filmgs? And after it has been classified, what likelihood is there that in innumerable instances the actual character will be properly determined? Prospecting will then have become a 'lost art.' With the greatest respect and admiration for the splendid work that has been and will be accomplished by the government geologists, the writer feels that they would be the last to claim that they could perform such miracles. But it may be urged that the determination shall be made by the Government after the claim is filed on by the 
mineral claimant. One can imagine the delay and intervening uncertainty of title which would result if some prospector in a remote part of the public domain had to notify a government inspector of his desire to acquire title to a claim and had to await the arrival and inspection and confirmation of report of the government agent. The writer has personal knowledge of a case where the applicant had to wait two years for the government inspector's report on a patent application for a lode mine existing in a remote and mountainous region of California. This instance is not cited by way of complaint, but merely as evidence of what will inevitably be the condition if the burden of classifying the character of the land is shifted from the prospector to the Government. It means abandoning the right of the miner to determine for himself, by discovery, the character of the land he seeks to acquire, and compelling the Government to assume the burden. And who is to pay the expense of such government inspection and determination? When the government inspector arrives on the ground will he not, in all probability, in the great majority of cases, base his determination of the character of the land on the same evidences that the prospector and miner himself ordinarily accept as a sufficient discovery?

Under the present law the prospector knows that as soon as he has made his discovery he is entitled to his ground and can enforce his right in the courts, where the long line of well considered decisions on the question of discovery will be followed. When discovery has been abolished, however, he can have no sucl assurance. The protection of the courts based on long established precedent is no longer his. The determination of the character of the land will rest elsewhere, and the miner will have sacrificed one of his strongest safeguards, founded on centuries of mining experience.

The element of discovery is firmly established in our system of mining law, as is evident from the following expressions of opinion by the Supreme Court of the United States:

"Discovery is the all-important fact upon which title to mines depends." (Lawson v. United States M. Co., 207 U S. I, I3.)

"The whole scope of the chapter (Chap. 6 of Title 32 , Rev. Stat.) is the acquisition of title from the United States to mines and mineral lands, the discovery of the mineral being, as stated, the initial fact. Without that no rights 
can be acquired." (Creede and Cripple Creek M. \& M. Co. v. Unita T. M. \& T. Co., I96 U. S., 337, 345.)

"In all legislation, whether of Congress or of the State or Territory, and by all mining regulations and rules, discovery, and appropriation are recognized as the sources of title to mining claims, and development, by working, as the condition of continued ownership, until a patent is obtained. And whenever preliminary work is required to define and describe the claim located, the first discoverer inust be protected in the possession of the claim until sufficient excavations and development can be made, so as to disclose whether a vein or deposit of such richness exists as to justify work to extract the metal. Otherwise, the whole purpose of allowing the free exploration of the public lands for the precious metals would in such cases be defeated, and force and violence in the struggle for possession, instead of previous discovery would determine the rights of claimants." (Erhardt v. Boaro, II3 U. S., 527-535.)

The foregoing is sufficient to indicate that discovery has played an important part in the history of mining law of the world and is the most vital requisite of the law as it exists in the United States today. Not only is this fundamental requirement incorporated in the federal statutes, but practically every mining state in the West has enacted this provision into its supplementary statutes. If discovery be abolished, not only must the federal statutes be amended, but each state will be compelled to alter its own statutes to harmonize.

More important than all else, the mining laws with relation to each other, and with relation to all of our public-land laws, have, during the years of their existence, been interpreted by the courts; and we have now built up on these laws a superstructure consisting of a long line of decisions worked out after years of painstaking effort, harmonizing and correlating and unifying not only the mining laws themselves, but also these laws in their relation to the non-mineral public-land laws. Decisions involving the effect of discovery of mineral exist with relation to homesteads, townsites, desert lands, timber lands, railroad lands, state lands, national forests, etc., and alinost every imaginable problem that can arise where discovery is involved has sooner or later been presented and decided. This judicial interpretation of the effect of these laws with relation 
to one another is as important in its way as is the organic law itself which it interprets. It is more important in one sense, for the fundamental law may be enacted 'over night,' as it were, while the judicial interpretation and harmonizing of these laws is a matter of a great many years of laborous development.

The law as it exists is now well understood all through the inining regions. Rights innumerable have become vested and are being exercised, and to make a radical change will materially unsettle conditions for years to come. To wipe out at one stroke all of these statutes and all of this superstructure of judicial interpretation will be a most serious mistake unless something materially better is offered in its stead. The burden rests heavily on the proponents of revision to establish this, for we are giving up the result of years of labor and cannot afford to take in exchange some substitute that somebody or other thinks will improve conditions, unless it is quite certain that it actually will have that claimed beneficial effect. We must have some valid reasons that cannot be satisfactorily covered by amendment to the existing law.

No one conversant with the facts, can, however, fail to recognize that the existing mining law is deficient in many respects and has been stretched to cover conditions it was never intended to govern. This is particularly true in the case of a discovery requirement as applied to deep-lying oil-bearing strata, zones of secondary enrichment constituting the so-called 'copper porphyries,' and gold placers of Alaska where the 'pay streak' can only be reached by sinking through many feet of frozen overburden. To such deposits the rigid discovery requirements should not apply. But, on the other hand, because the law as to discovery has imperfections is no reason for abolishing it in toto unless its shortcomings are incurable by amendment.

This entire condition can be remedied very sinply by applying to such exceptional cases the following equitable doctrine which has already been announced many times by the Supreme Court of California:

"If a qualified person peaceably enters upon public lands of the United States for the purpose of discovering oil or other valuable mineral deposits therein, and such land is at the time unoccupied, and there is at the tine no valid inineral location or lawful entry thereon, under the land laws of the United States, such person has the right to continue 
in possession so long as he continues to occupy the same to the exclusion of others, and diligently and in good faith prosecutes thereon the work of endeavoring to discover such mineral therein."8 (Smith v. Union Oil Co., I35 Pac., 966-967.)

The citation from Erhardt v. Boaro, already quoted, is also an announcement of the same doctrine by the Supreme Court of the United States. It is true that some courts have limited the locator's right prior to discovery to his pedis possessio, or ground that he actually has in his physical possession, ${ }^{9}$ but it would seem that this is taking too narrow a view of the situation where the locator is using due diligence in perfecting a discovery. The United States, through its mining statutes, has extended to him a tacit invitation by declaring that all of its mineral lands are "free and open to exploration and purchase." When he enters upon such lands in good faith, intending to demonstrate their mineral character by making a discovery with reasonable diligence, the Government should protect him to the extent of his located boundaries of lawful size and thereby prevent acts of violence and unseemly contests in a struggle for possession.

The California doctrine is clearly the equitable one, and if there is any uncertainty about its being the law, it can readily be codified by Congress as an amendment to the mining statutes. This will overcome many of the objections to the rigid discovery requirement.

There is another objection which has been raised against the existing law by reason of the possibility of agricultural filings being made on such lands containing deep-lying mineral before the mimeral claimant has had a chance to make a discovery. The remedy for such cases is clearly one which has already been utilized in the oilfields and in the case of 'copper porphyries.'10

Where such areas have been satisfactorily demonstrated by adjacent indications or discoveries of mineral to contain, in all probability, the continuation of such deposits, the land depart-

${ }^{8}$ Weed v. Snook, 144 Cal. 439, 444; Miller v. Chrisman, 140 Cal. 440, 447; Borgwardt v. McKittrick Oil Co., 164 Cai. 650, 658-9; see also Whitney v. Straup, (Wyo.), 95 Pac. 849, 855; Phillips v. Smith, (Ariz.), 95 Pac. 91, 92.

9 Hanson v. Craig, 170 Fed., 62; Gemmel v. Swain (Mont.), 72 Pac., 662 .

10 34th Ann. Rep. Director U. S. Geo1. Surv., p. 154; also, Bulletin 537, U. S. Geol. Surv., pp. 40-41. 
ment can withdraw them from agricultural entry for a sufficient period of time to enable prospective mineral claimants to demonstrate the actual presence of mineral by discovery. Under existing law the Government can in this way extend every protection to the miner. The possibility of serious difficulty from an agricultural claimant prior to discovery is rather remote even in the absence of a withdrawal from agricultural entry. The agricultural claimant must file his application under the land laws in the land office, and the miner has every opportunity to call the land department's attention to the probable mineral character of the land by protest. The department has in several instances already decided that it is not necessary that there be an actual discovery of mineral on the land in order to cause it to deny the agricultural application or withhold determination pending discovery work by the mineral claimant. Adjoining indications of mineral are sufficient to justify the department in taking such action. ${ }^{1 x}$

The experience of 'scrippers,' homesteaders, and other pseudoagricultural claimants in the oilfields is evidence of the fact that the Government will not permit land with mineral indications to be patented under the non-mineral laws. If this protective action has not been exercised widely enough, it is possible to extend it, simply by convincing the land department of an existing necessity. The miner's status can be further strengthened, if deemed necessary, by appropriate legislation.

It will appear from the foregoing discussion that to do away with the necessity of discovery is to amend our mining law fundamentally. It shifts the power of establishing the character of the land in the first instance from the miner himself to the Government. Whereas the miner has in the past been given the preference, wherever he could establish a valid discovery, any alteration in the law such as proposed gives rise to new and unfathomed complications. Where agricultural claimants assert title to the same land, and where national forests are involved, the miner is not likely to profit by doing away with discovery. Under a new law placing the determination of the question of mineral character in the hands of others, he may awaken to the fact that he has "sold his birthright for a mess of pottage."

11 Skinner v. Fisher, 40 L. D., 112, 116; also, see an unreported decision appearing in the Mining and Scientific Press of July 27, 1907, p. 123. 
It may be that the difficulties pointed out can be overcome and that some one can suggest an alteration of our mining code, fitted to our conditions, which will not work a hardship on the miner. But the old adage must be kept in mind that it is easier to tear down than to build up. The proposal of abolishing the extralateral right also deserves careful consideration, but the subject is too large to be dealt with in this article.

WILLIAM E. COLBY.

San Francisco, Cal. 